\title{
Ethical Leadership Behaviour Of Heads Of Department And Job Performance Of Academic Staff In South-South Universities, Nigeria
}

\author{
Dr. Sunday I. Efanga \\ Department of Curriculum Studies/ Educational Management and Planning, \\ University of Uyo, Uyo. \\ Dr. Roseline C. Effiong \\ Department of Curriculum Studies/ Educational Management and Planning, \\ University of Uyo, Uyo. \\ Joseph M. Nwokomah \\ Department of Curriculum Studies/ Educational Management and Planning, \\ University of Uyo, Uyo.
}

\begin{abstract}
The purpose of this study was to determine the relationship between ethical leadership behaviour of heads of department and job performance of academic staff in SouthSouth Universities, Nigeria. Three null hypotheses formulated for the study were tested using the simple regression analysis at 0.05 level of significance, 1 and 998 degrees of freedom. The ex-post facto survey design was used. The study population was 739 heads of department and 14,000 academic staff in public Universities in South-South, Nigeria. The multi- stage sampling technique involving stratified sampling and simple random sampling was used to select a sample of 204 heads of department and 1020 academic staff for the study. A researcher made instruments, "Ethical Leadership Behaviour of Heads of Department Questionnaire (ELBHDQ)" and "Job Performance of Academic Staff Questionnaire (JPASQ)" with items measured on 4-point rating scale were used for data collection. The instruments were given to two validates in educational management and educational evaluation in the University of Uyo to determine the validity. The reliability of the instruments was also determined by internal consistency method using the cronbach's alpha analysis in which coefficients of 0.76 and 0.82 showed that the instruments were reliable. All the three hypotheses were rejected since the calculated F-values of $15.19,6692.30$ and 2333.33 were greater than the critical F-value of 3.84 thus indicating that there was a significant relationship between ethical leadership behaviour of heads of department and job performance of academic staff in South-South Universities in Nigeria. It was concluded that management should maintain high ethical standards in the Universities so that the employees' job performance would improve. Among the recommendations was that the University management should enforce disciplinary actions against unethical conduct. Indiscipline staff with clear cases of misconduct should be sanctioned or sacked.
\end{abstract}

Keywords: Ethical leadership behaviour job performance.

\section{INTRODUCTION}

Ethics is an element of philosophy that reflects upon good and evil and upon moral norms. It defines the purpose of life and the means to achieve it. Ethics is a system of values and laws that defined what is right and what is good (Badah, Alaoamlh, Alsaleem and Al-Ali, 2013). Ethics is basically concerned with rightness and goodness, and the oughtness of conduct. It is derived from the Greek term ethos meaning custom or way of life. Ethics shapes the life of all 
individuals in the society. Bar-Tal and Saxe (2001) noted that ethics enables the individual to understand why certain actions deserve blame and others praise. This will help an individual to adjust his life. Bucholz (2003), in his work on business ethics, saw ethics as the guiding values; principles and standards that help people determine how things ought to be done. Ethics is therefore a standard of morality that guides individual and organization in following certain codes of conduct when dealing with each other. Ethics can also be regarded as a set of standard of right and wrong established by a particular group and imposed on members of that group as a means of regulating and setting limit on behaviour (Joseph, 2010). It is concerned with right versus wrong, good versus bad. In the University system there are rules and regulation guiding the conduct of members called codes of ethics or ethical issues. Ethical issues are principles that serve as guidelines for both individuals and organizations. The codes of ethics are necessary due to reported cases of questionable characters, unethical behaviours exhibited by some workers. Heads of Department are the mirrors in which others look unto in the departments; therefore their behaviours should be morally right.

There are rules and regulation that members of the University community must conform to and these are called codes of ethics. Codes of ethics are the rules which are supposed to govern the conduct of members of a given profession (Shaw, 1993). The members of a profession are understood to have agreed to abide by those rules as a condition of their engaging in that profession. Every profession and organizations have their code of conduct. A code of ethics is a formal and written statement of ethical commitments and expectations (Shermerhorn, 2002). The rules and regulations that have to do with good morals are always written down and given to the employees. Dessler and Varkkey (2008) stated that ethics code is 'a document that memorializes the standards the employer expects its employees to adhere to" (p. 562). The rules and regulation embedded in the document are for the purpose of ensuring adequate standards of practice and uniformity in operation.

Universities have extended their efforts beyond the classroom by taking an obvious step in the direction of having rules that prohibit lying, cheating, stealing, violent behaviour, interference with freedom of expression, or other acts that violate fundamental human rights. University of Uyo (2011) in maintaining their ethical standards and discipline of staff outlined the following misconduct in the regulations governing staff conditions of service.

These are lateness, proven poor performance of duty, dishonesty, drunkenness, absence from duty without leave, abandonment of duty, plagiarizing journal article (s) and book (s) or other such materials, demand for, and acceptance of bribe or corruption, alteration of examination grades/marks, sexual harassment, fighting while on duty, unauthorized disclosure of official information, and any other such acts (pp.89-91).

\section{Ethical Leadership Behaviour}

Workplace ethics are principles of conduct used to govern the decision-making and behaviour of an individual or group of individuals in the workplace (Rue and Byars, 2000). Good work attitudes are often desired by all employers of labour from their employees. The concept of work ethics relates to the desirable work attributes, values and beliefs expected from employees (Brouchle and Azam, 2004). Ethical behaviour are behaviours that ought to prevail while unethical behaviours violate given standard as to what ought to prevail. Work ethics is therefore concerned with attributes or behaviours that ought to prevail or to be exhibited by individuals within the dictates and tenets of the norms of the workplace, irrespective of the individual's occupational classification (Essien, 2007). It is based on the cultural norms, values and beliefs of the employees. 
It is that which is accepted as good and right as opposed to unethical behaviour, that is bad or wrong in a particular workplace setting (Obeki, 2002). Ethical standards are usually contained in an organizational rules and regulations or codes of conduct. When these rules and regulations or codes of conduct are floated, they attract queries or disciplinary actions. Ethical behaviour is therefore the principle relating to right and wrong. According to Kreitner and Kinicki (2001), ethical behaviours are pattern of behaviour to which individuals and groups are expected to conform.

They include key principles such as honesty, integrity, fairness, and concern for others. It is a situation whereby leaders engage in behaviour that benefits others and refrain from behaviour that can cause harm to others (Toor and Ofori, 2009). Ethical leaders possess traditional leadership traits such as integrity, honesty and trustworthiness. Ethical leadership includes transactional leader behaviours such as setting ethical standards and holding followers accountable for ethical conduct (Bello, 2012). This means ethics must indeed begin at the top and flow down the strata. Leaders cannot shrink from their obligations to set a moral example for their followers. Employees want to be associated with managers that are honest, credible, respectful and fair in all their dealings with others.

The ethical behaviours of an administrator in a workplace as outlines by Obeki (2002) include: punctuality, loyalty, honesty, obedience to the constituted authorities and lawful orders, positive attitude to work, trust, respect, teamwork, adherence to the established dress code, observance of established safety rules, observance of due process/respect for hierarchy /constituted authorities. Otong (2013) noted that "a strong organizational structure founded on ethical principles and sound values is a necessary foundation for organizational success" ( $p$. 268). Management must always strive to maintain good ethical behaviours at workplace. This will help in ensuring that employees act ethically and cases of "monkey see, monkey do" will be wiped away. This implies that the boss often has a determining effect on whether his or her employees do the ethical thing.

The key component to workplace ethics and behaviour is integrity that is being honest and doing the right thing at the right time. Leadership integrity is the leader's honesty, credibility, and consistency in putting ethical values into action (Schermerhorn, 2002). Integrity has to do with having good reputation and image in the society. It involves doing what is morally right and maintaining sound ethical behaviours. It should be of universal application.

The level of commitment to the job by the management staff will encourage and motivate all other workers to put in their best at the job. Commitment is the hardwork and loyalty that an employer gives to the organization. Bello (2012) defined commitment as "loyalty and attachment of an individual or group to the organization" (p. 233). This suggests that organizational commitment is a state in which an employee identifies with a particular organization and its goals and wished to maintain membership in the organization. Commitment therefore is defined as loyalty to, identification and involvement with an organization. This identification, expressed through the adoption of organizational goals in which the individuals take pride in the organization, participate with interest in its activities, and speak positively or favorably about their connection with the organization (John and Taylor, 2000).

Discipline is very vital in any educational institution so as to achieve the goals of education. Management staff, and lecturers require self-discipline in order to instill discipline in others. Aguba (2009) stated that "discipline means self-control, the control of conduct including habits, action, desires, emotions, impulses and general behaviour" (p. 189). Inyang and 
Akpama (2002) defined discipline as "the state of employees' self-control and orderly conduct present within an organization" (p.161). Self-discipline means having self-control over certain actions which makes an individual to do what is morally right at all times.

Self-discipline is very important in a work place. Management staff should be self-disciplined before they can instill discipline in the life of their followers. Self-discipline involves hardwork and dedication to duties that enables the accomplishment of organizational goals. Work is not done to avoid disciplinary measure but for goal accomplishment. Nkang (2002) asserted that for good behaviour to be imbibed, one must build up a level of self-control such that proper habits can follow without necessarily waiting for disciplinary actions to be employed. When self-control is built, management tasks in terms of supervision and discipline becomes simple.

\section{Null Hypotheses}

The following null hypotheses were formulated to guide the study:

1. There is no significant relationship between integrity by Heads of Department and job performance of academic staff in South-South Universities in Nigeria

2. There is no significant relationship between commitment by Heads of Department and job performance of academic staff in South-South Universities in Nigeria

3. There is no significant relationship between self-discipline by Heads of Department and job performance of academic staff in South-South Universities in Nigeria.

\section{METHODOLOGY}

The study used ex-post facto design approach. This was because the researcher had no direct control of the independent variables hence their manifestations had already occurred.

The study population comprised all the heads of department, academic staff and full-time undergraduate students in the public Universities in South-South, Nigeria. There are 12 public Universities in the South-South zone of Nigeria, with a total population of 739 heads of department and 14,000 academic staff (source: Directorate of Personnel Affairs of the Universities; and online from National Universities Commission, 2016).

\section{Sample and Sampling Technique}

The sample consisted of 204 heads of department and 1020 academic staff drawn from 5 Universities selected for the study in the South-South, Nigeria. The multistage sampling procedure involving stratified sampling technique based on faculties and simple random sampling technique was used in selecting the respondents for the study. Three States out of the six states in the South-South were randomly selected for the study, which were Akwa Ibom, Cross River and Rivers State. Three Federal and two state Universities located in these states were used for this study. $62.5 \%$ of heads of department and $16.9 \%$ of academic staff were selected from the five sampled Universities giving a total of 204 heads of department and 1020 academic staff. In each sampled department, 5 academic staff and 5 students were used as respondents for the study corresponding to 1020 academic staff, 1020 students in the 204 departments. Students were better disposed to assess the academic staff and were used as raters for the job performance of academic staff questionnaire.

\section{Instrumentation}

The data collection tools for this study were "Ethical Leadership Behaviour of Heads of Department' Questionnaire (ELBHDQ)" and "Job Performance of Academic Staff Questionnaire (JPASQ)". The two instruments (ELBHDQ and JPASQ) were given to two lecturers who are experts in the field of educational management, and an educational evaluation specialist in the 
Faculty of Education, University of Uyo, for inspection and moderation of every item in terms of face value, clarity, language and content.

\section{Reliability of the Instruments}

Internal consistency reliability estimate was carried out for the instruments. Ethical Leadership Behaviour of Heads of Department Questionnaire (ELBHDQ) and Job Performance of Academic Staff Questionnaire (JPASQ) were administered once to 20 academic staff and 20 students in 4 Departments in the Faculty of Education, University of Uyo, which were not part of the sampled group. The scores obtained were subjected to Cronbach's alpha analysis. The reliability coefficients of 0.76 and 0.82 were obtained for ethical leadership behaviour variables and job performance respectively, which were considered substantially high enough to justify the use of the instruments.

\section{Administration of the Instruments}

The Ethical Leadership Behaviour of Heads of Department Questionnaire (ELBHDQ) and Job Performance of Academic Staff Questionnaire (JPASQ) were administered by the researcher and four trained research assistants who were briefed on the purpose of the study, administration and collection of the instruments. Copies of the questionnaire were given to students who responded to job performance of academic staff questionnaire (JPASQ). The academic staff were also given copies of ELBHDQ to respond to ethical leadership behaviour of heads of department. One thousand and twenty copies of JPASQ were given out to students and one thousand and five copies were returned, but five were not properly filled and were discarded. While one thousand and twenty copies of the ELBHDQ were given out to academic staff and one thousand and two were returned. The success rate was (98.0\%) for JPASQ and (98.2\%) for ELBHDQ. The researcher used a total of 1000 completed copies of JPASQ and 1000 completed copies of ELBHDQ for data analysis. Therefore, 1000 academic staff assessed 200 heads of department and 1000 students assessed 1000 academic staff.

\section{Data Analysis}

All responses obtained from section B of the ELBHDQ and JPASQ questionnaires were scored 4, 3, 2 and 1 for strongly agree, agree, disagree and strongly disagree. The summation of scores for items designed to measure a particular variable constituted the score for that variable. 1000 set of scores were obtained from 1000 students on JPASQ and 1000 set of scores were also obtained from 1000 academic staff on ELBHDQ. The simple regression analysis was used to analyze data for the three null hypotheses formulated to guide the study. All hypotheses were tested at 0.05 alpha levels, 1 and 998 degrees of freedom.

\section{RESULTS}

Table 1: Simple regression analysis relating integrity by heads of department and job performance of academic staff in Universities

\begin{tabular}{llllllc}
\hline Source of Variation & Sum of squares & df & $\begin{array}{l}\text { Mean } \\
\text { square }\end{array}$ & F-cal & F-crit & Decision \\
\hline Regression & 50.67 & 1 & 50.67 & 15.19 & 3.84 & $*$ \\
Residual & 3306.93 & 998 & 3.3136 & & & \\
Total & 3357.60 & 999 & & & & \\
\hline
\end{tabular}

*Significant at $\mathrm{P}<.05 ; \mathrm{df}=1$ and 998

The calculated F-value of (15.19) is greater than the critical F-value of (3.84) at 0.05 level of significance, 1 and 998 degrees of freedom. Hence, the null hypothesis that there is no significant relationship between integrity by heads of department and job performance of academic staff in South-South Universities in Nigeria is rejected. 
Table 2: Simple regression analysis relating commitment by heads of department and job performance of academic staff in Universities

\begin{tabular}{llllllc}
\hline Source of Variation & $\begin{array}{l}\text { Sum of } \\
\text { squares }\end{array}$ & df & $\begin{array}{l}\text { Mean } \\
\text { square }\end{array}$ & F-cal & F-crit & Decision \\
\hline Regression & 2925.93 & 1 & 2925.93 & 6692.30 & 3.84 & $*$ \\
Residual & 431.67 & 998 & 0.4321 & & & \\
Total & 3357.60 & 999 & & & & \\
\hline
\end{tabular}

*Significant at $\mathrm{P}<.05 ; \mathrm{df}=1$ and 998

Since the calculated F-value of (6692.30) is greater than the critical F-value of (3.84) at 0.05 level of significance and 1 and 998 degrees of freedom, the null hypothesis that there is no significant relationship between commitment by heads of department and job performance of academic staff in South-South Universities in Nigeria is rejected.

Table 3: Simple regression analysis relating self-discipline by heads of department and job performance of academic staff in Universities

\begin{tabular}{lllllcc}
\hline $\begin{array}{l}\text { Source of } \\
\text { Variation }\end{array}$ & $\begin{array}{l}\text { Sum of } \\
\text { squares }\end{array}$ & df & $\begin{array}{l}\text { Mean } \\
\text { square }\end{array}$ & F-cal & F-crit & Decision \\
\hline Regression & 2350.23 & 1 & 2350.23 & 2333.33 & 3.84 & $*$ \\
Residual & 1007.37 & 998 & 1.009 & & & \\
Total & 3357.60 & 999 & & & & \\
\hline
\end{tabular}

* Significant at $\mathrm{P}<.05$; $\mathrm{df}=1$ and 998

Since the calculated F-value of (2333.33) is greater than the critical F-value of (3.84) at 0.05alpha level of significance and 1 and 998 degrees of freedom, the null hypothesis that there is no significant relationship between self-discipline by heads of department and job performance of academic staff in South-South Universities in Nigeria is rejected.

\section{DISCUSSION OF FINDINGS}

The discussion of findings is done under subheadings based on the three null hypotheses used for the study.

Integrity by Heads of Department and Job Performance of Academic Staff in Universities Findings from the data in Table 1 indicate that there is a significant relationship between integrity by heads of department and job performance of academic staff in South-South Universities in Nigeria. It was discovered that when the heads of department are honest in their administrative dealings, are well dressed and respectable, do not give marks in exchange of sexual favours or economic gain, and follow due process in administration, lecturers' ethical work behavior will be affected positively and this will also to a smaller extent improve their job performance. Bello (2012) noted that good quality relationship built on respect and trust are the most important determinants of organizational success. Heads of department who do not maintain high ethical standard in an organization are disloyal and dishonest and cannot correct their subordinates. They cannot give what they do not have as such academic staff performance will be very poor.. Findings from this study are in line with the work of Joseph (2010) on employee ethical behaviour and organizational performance. The possible explanation for this result of findings is that when heads of departments maintain high degree of integrity, other staff will exhibit this good moral and will try to uphold it leading to improve job performance. 


\section{Commitment by Heads of Department and Job Performance of Academic Staff in Universities.}

The results of analysis of data in this study as shown in Table 2 reveal that there is a significant relationship between commitment by heads of department and job performance of academic staff in South-South Universities in Nigeria. This result of finding is in agreement with the work of Quzug (2005) which revealed that there is a significant difference in the commitment degree of the heads of academic department in the Jordanian public Universities regarding the professional ethics attributed to the two variables of specialization and academic rank, from the view of the faculty members.

A possible explanation of this result is that when the leaders are committed to their work, their subordinates will also show a high degree of commitment to the organization leading to high job performance. The head of department who are not committed to their jobs would not create time for adequate supervision and monitoring of activities of other staff.

\section{Self-Discipline by Heads of Department and Job Performance of Academic Staff in Universities.}

The results of analysis of data in this study as indicated in Table 3 reveal that there is a significant relationship between self-discipline by heads of department and job performance of academic staff in South-South Universities in Nigeria. The implication of this findings is that heads of department who set good examples of disciplinary behaviour by adhering to the established rules and regulations will likely correct other staff with misbehaviour and encourage them to be self-disciplined. This involves leading by example. A disciplined administrator will make staff to be more effective and hardworking as staff will not exhibit poor attitude to work due to fear of being sanctioned. When management staff are not selfdisciplined, the subordinates may also show negative attitude to work which will affect the job performance.

When strict disciplinary measures are put in place by heads of department, lecturers would be up to their tasks and the performance will be high. Heads of department therefore must be disciplined so as to enforce discipline among others.

\section{CONCLUSION}

Based on the findings, it was concluded that ethical leadership behavior of heads of department has a positive effect on job performance of academic staff. Heads of department who behave ethically and exhibit good leadership ethics are capable of creating a long lasting employees job performance while unhealthy ethical leadership behaviour can only drive for a while but will eventually lead to poor job performance.

It, therefore, becomes imperative for management and employees to try and promote acceptable or healthy leadership behaviour in the world of work so as to achieve excellent job performance which can enable the organization to grow in leaps and bounce. Heads of department must create an ethically acceptable work environment for all staff, serve as role models and put all mechanisms in place for the development of responsible and ethically minded employees. By so doing the performance of academic staff will improve since ethical leadership behaviour will surely impact positively on job performance. Corruption, lateness to work, absenteeism, and other level of moral decadence in our institution of learning will reduce drastically thereby setting a sustainable work environment that will reverse the unacceptable work behaviour and place the teaching profession in a high status. This will have a positive influence on the student's performance and behaviour as such the image of our country Nigeria will be raised. 


\section{RECOMMENDATIONS}

The following recommendations were made based on findings of the study:

1. University management should ensure that a whistle blowing or ethical concerns procedure is established for internal problem solving. Information box should be kept at strategic point so that students and staff can report cases of unethical behaviour among staff.

2. The University management should endeavour on their part to reward employee's actions that are in line with the ethical demand made on staff and promotion should also be based on hard work and commitment to goal. On the other hand, employees that do not meet such demands should be sanctioned or punished.

3. University management should enforce disciplinary actions against unethical conduct. Indiscipline staff with clear cases of misconduct should be sanctioned or sacked. Also, the University should ensure to have code of ethics and a copy of this work place ethics Should be given to the staff.

\section{References}

Aguba, C.R. (2009). Educational Administration and Management: Issues and Perspectives. Enugu: Tons and Tons PDS.

Badah, A. M., Alaoamlh, H., Alsaleem, B. and Al-Ali, Y. (2013). Commitment Degree of Jaresh University Administration to the Academic Performance Ethics. European Scientific Journal, 9 (4): 252-269.

Bar-Tal, J. C. and Saxe, P. C. (2006). Building Capacity for Ethical Leadership Preparation Programs. Journal of Scholarship and Practice, 3 (1): 11-17.

Bello, S. M. (2012). Impact of Ethical Leadership on Employee Job Performance. International Journal of Business and Social Science, 3 (11): 228-236.

Brouchle, P. E. and Azam, M. S. (2004). Factorial in Variance of Occupational Work Ethic Inventory. Journal of Vocational Education, 29 (2): 25-49.

Bucholz, R. A. (2003). Fundamental Concepts and Problems in Business Ethics. Eaglewood Cliffs, NJ: Prentice-Hall. Dessler, G. and Varkkey, B. (2008). Human Resource Management (11 ${ }^{\text {th }}$ ed.) New Delhi: Pearson Prentice Hall. Essien, E. O. (2007). Demographic Factors and Occupational Work Ethics among Technical Educators in Akwa Ibom State. Unpublished M. Ed. Thesis, University of Uyo, Uyo.

Inyang, B. J. and Akpama, A. M. (2002). Personnel Management Practice in Nigeria. Calabar: Merb.

Joseph, K .O. (2010). Effects of Ethical Behaviour on Organizational Performance: Evidence FRC Three Service Organizations in Lagos, Nigeria. Journal of Research in National Development, 8 (1): 1-10.

Kreitner, R. and Kinicki, A. (2001). Organizational behaviour (5 ${ }^{\text {th }}$ ed.). New York: Irwin/McGraw-Hill.

Nkang,I. E.(2002). Fundamentals of Educational Administration, Planning and Supervision. Uyo: Afahaide and Bros.

Obeki, S. O. (2002). Administrative Skills, Procedures and Best Practices for University Administrators and Administrative Personnel. Benin: Mindex.

Otong, E. U. (2013). Entrepreneurship Development in Nigeria. Uyo: Danwill Printing Press.

Quzug, M. N. (2005). Commitment Degree of the Heads of the Academic Departments of the Jordanian Public Universities to the Professional Ethics, from the Faculty Members Points of View. Unpublished M.AThesis, Amman Arab University for Graduate Studies, Amman, Jordan.

Rue, L .W. and Byars, L. L. (2000). Managing Skills and Application. New York: Irwin McGraw-Hill, p. 128.

Schermerhorn, J. R. (Jr) (2002). Management (7th ed.). New York: John Wiley and Sons.

Shaw, W. H. (1993). Social and Personal Ethics. Belmont, California: Wadsworth.

Toor, S. and Ofori, G (2009). Ethical Leadership: Examining the Relationships with Full Range Leadership Model, Employee Outcomes, and Organizational Culture. Journal of Business Ethics, 90:533-547.

University of Uyo (2011). Regulations Governing Staff Conditions of Service. Uyo: Modern Business Press. 